\title{
PEMBERDAYAAN PEREMPUAN MELALUI WIRAUSAHA PENGOLAHAN BUAH SIWALAN DI DESA BANUAJU TIMUR KECAMATAN BATANG-BATANG
}

\author{
Yayuk Sugiarti ${ }^{1)}$, Sutrisni ${ }^{2)}$ \\ Fakultas Hukum, Universitas Wiraraja \\ E-mail : yayuksugiarti66@yahoo.co.id \\ E-mail : sutrisnioke@yahoo.com
}

\begin{abstract}
ABSTRAK
Pengabdian ini membahas adanya pemberdayaan perempuan melalui pelatihan terhadap perempuan di desa Banuaju Timur Kecamatan Batang-Batang terkait adanya pengolahan buah siwalan menjadi makanan yang beragam (bervariasi) misalnya manisan sehingga lebih menarik dan mampu meningkatkan harga jual yang berpengaruh terhadap pendapatan masyarakat serta mewujudkan desa mandiri.Tujuan adanya pengabdian kepada masyarakat ini pada akhirnya bagaimana kita memberdayakan perempuan dengan membentuk suatu organisasi yang didirikan oleh masyarakat melalui adanya pelatihan sehingga mereka mampu berpikir lebih luas bahwa untuk meningkatkan harga jual di pasar, buah siwalan tidak saja dijual dalam bentuk buah segar akan tetapi dapat diolah menjadi makanan yang mempunyai nilai jual pasar lebih tinggi sehingga berpengaruh terhadap pendapat masyarakat. Pengabdian kepada masyarakat ini menggunakan metode pelatihan yaitu ceramah digunakan untuk menjelaskan tentang teori bermacam-macam pengolahan buah siwalan; metode praktek digunakan untuk mempraktekkan berbagai macam pengolahan buah siwalan menjadi manisan dll; serta metode diskusi dilakukan setelah pelatihan selesai sehingga kita mengetahui sejauh mana respon peserta terhadap kegiatan ini. Adanya pelatihan buah siwalan menjadi manisan ini, mampu meningkatkan partisipasi masyarakat dengan mengembangkan kelembagaan masyarakat; meningkatkan kemandirian masyarakat dalam mengolah sumberdaya yang ada sesuai dengan kondisi sosial dan budaya yang seimbang dari aspek ekologis dan ekonomis; serta mampu menambah pendapatan mereka untuk kebutuhan sehari-hari dengan mengolah buah siwalan menjadi manisan
\end{abstract}

Kata kunci : pemberdayaan, perempuan, buah siwalan

\section{Pendahuluan}

Pemberdayaan adalah upaya pemberian daya atau peningkatan keberdayaan untuk memandirikan masyarakat agar mampu berpartisipasi aktif dalam segala pembangunan. Masyarakat berinisiatif untuk memulai proses memperbaiki kehidupannya dengan cara yang masih tradisional sehingga mereka masih sulit menerima kemajuan teknologi modern seperti saat ini.

Desa Banuaju Timur Kecamatan BatangBatang adalah suatu wilayah potensial penghasil buah siwalan karena daerahnya kering dan tanah berpasir. Mayoritas penduduk di desa Banuaju Timur adalah petani yang hanya mengandalkan hasil dari bercocok tanam buah siwalan dan jika saat itu tidak laku terjual karena mudah busuk hal ini mempengaruhi harga jual yang cenderung sering menurun. Kurangnya pengetahuan dan keterampilan, buah siwalan ini hanya dijual dalam bentuk buah segar tanpa pengolahan. Salah satu upaya untuk menambah harga jual yaitu dengan mengolah buah siwalan menjadi manisan. Hal ini mendorong para perempuan untuk dapat membuka peluang usaha baru dan ikut berkontribusi dalam meningkatkan ekonomi keluarga sehingga dapat mencukupi kebutuhan keluarga. 
Umumnya perempuan di desa Banuaju Timur sebagai buruh tani yang mana pekerjaan tersebut tidak dapat diperoleh setiap hari sehingga pada akhirnya bagaimana kita memberdayakan perempuan yaitu membentuk suatu organisasi yang didirikan oleh masyarakat dengan melakukan aktifitas seperti pelatihan dalam menciptakan buah siwalan dengan pengolahan yang beragam seperti contohnya manisan agar dapat meningkatkan pendapatan perempuan di desa Banuaju Timur Kecamatan Batang-Batang. Pelatihan ini diharapkan dapat membantu ekonomi masyarakat khususnya ibu-ibu di desa Banuaju Timur.

\section{Metode}

Kegiatan pengabdian ini dilaksanakan di desa Banuaju Timur yang berjarak kurang lebih $30 \mathrm{~km}$ dari Universitas Wiraraja tepatnya di rumah Ibu Nurwahida Kecamatan Batangbatang dan dilaksanakan pada bulan April September 2019 diikuti oleh tim PKM serta 4 orang mahasiswa. Kegiatan ini diikuti pula oleh 30 orang ibu-ibu yang sehari-hari sebagai ibu rumah tangga. Pengabdian kepada masyarakat oleh dosen Fakultas Hukum Universitas Wiraraja ini dilaksanakan dalam bentuk memberikan pelatihan pengolahan siwalan menjadi manisan untuk meningkatkan perekonomian masyarakat di desa Banuaju Timur kecamatan Batang-Batang. Pelatihan ini menggunakan metode ceramah ( penjelasan terkait buah siwalan bisa diolah menjadi manisan), kemudian kita langsung mempratekkan cara membuat siwalan menjadi manisan.

\section{Hasil dan Pembahasan}

Pemberdayaan dapat diartikan sebagai upaya untuk memandirikan masyarakat agar mampu berpartisipasi aktif dalam segala aspek, karena itu pemberdayaan masyarakat harus dilakukan secara terus-menerus untuk meningkatkan harkat dan martabat masyarakat bawah yang tidak mampu melepaskan diri dari kemiskinan. Maksud dan tujuan tim PKM Universitas Wiraraja melakukan pemberdayaan perempuan melalui pengolahan buah siwalan yaitu:

a. Meningkatkan partisipasi masyarakat dengan mengembangkan kelembagaan masyarakat;

b. Meningkatkan kemandirian masyarakat dalam mengolah sumberdaya yang ada sesuai dengan kondisi sosial dan budaya yang seimbang dari aspek ekologis dan ekonomis

Tujuannya adalah terwujudnya kemandirian masyarakat dalam berusaha dengan kelembagaan yang tangguh sehingga masyarakat sejahtera. Pemberdayaan yang dilakukan oleh tim PKM Universitas Wiraraja melalui pelatihan pengolahan siwalan menjadi manisan yaitu:

a. Tahap persiapan

Pelatihan ini dimulai dengan tahap persiapan, yaitu tim berkoordinasi dengan Ibu Nurwahida bahwa tim PKM akan mengadakan kegiatan pemberdayaan perempuan melalui pelatihan pengolahan buah siwalan menjadi manisan. Hal ini mendapat respon baik dari Ibu Nurwahida, sehingga dapat meningkatkan perekonomian masyarakat di desa Banuaju Timur Kecamatan Batang-Batang.

b. Pelaksanaan

Kegiatan pelatihan dimulai pukul 10.00 WIB dan berakhir pukul 14.00 WIB.

1. Kegiatan dilakukan di rumah Ibu Nurwahida desa Banuaju Timur Kecamatan Batang-Batang;

2. Peserta yang hadir kurang lebih 30 orang dan mayoritas ibu rumah tangga;

3. Mereka tampak antusias dalam mengikuti pelatihan ini mulai dari awal sampai kegiatan ini berakhir. Mereka juga sudah mulai mahir bagaimana cara membuat siwalan menjadi manisan 
b. Meningkatkan kemandirian masyarakat dalam mengolah sumberdaya yang ada sesuai dengan kondisi sosial dan budaya yang seimbang dari aspek ekologis dan ekonomis;

c. Mampu menambah pendapatan mereka untuk kebutuhan sehari-hari dengan mengolah buah siwalan menjadi manisan

\section{Daftar Pustaka}

Gambar. Pelatihan pembuatan manisan buah siwalan

\section{Simpulan}

Berdasarkan pelatihan yang telah kami lakukan di desa Banuaju Timur Kecamatan Batang-Batang, maka tim menyimpulkan sebagai berikut:

a. Adanya pelatihan buah siwalan menjadi manisan ini, mampu meningkatkan partisipasi masyarakat dengan mengembangkan kelembagaan masyarakat;

Agusta, I. 2002. Metode Evaluasi Program Pemberdayaan. Humaniora Utama Press: Bandung

Eko, Sutoro. 2002, Pemberdayaan Masyarakat Desa, Materi Diklat Pemberdayaan Masyarakat Desa, Desember 2002

Suharto, E. 2005. Membangun Masyarakat Memberdayakan Rakyat, PT. Refika Aditama: Bandung

Mardikanto, Totok. 2015. Pemberdayaan Masyarakat. Alfabeta: Bandung 